DOI https://doi.org/10.18551/rjoas.2017-06.37

\title{
POTENTIAL FOR REVITALIZATION OF INSTITUTIONAL RICE FARMING ECOSYSTEM WITH ING IN THE OGAN KOMERING ILIR DISTRICT OF SOUTH SUMATRA PROVINCE
}

\author{
Aprini Nisma \\ Academy of Information Management \& Computer, Indonesia \\ Sriati, Asmani Najib, Maryadi \\ Faculty of Agriculture, University of Sriwijaya, Indonesia \\ *E-mail: nisma.aprini@gmail.com
}

\begin{abstract}
This study aims to analyze the factors that influence potential revitalization of institutional model of corporate farming. The method used is survey method. The analytical tool used to analyze the factors that influence potential for institutional revitalization with corporate farming models is Structural Equation Modeling (SEM) with PLS (Partial Least Square) program. The variables measured in the study are: 1) Human Resources (X1), 2) Management (X2), 3) Coaching (X3), 4) social environment of the culture (X4), 5) the characteristics of institutional farmer (X5), 6 ) farmers' knowledge about corporate farming (X6), 7) Potential Corporate farming (Y1), 8) Readiness of farmers to institutional corporate farming (Y2). The results show that the six variables significantly affect the potential for institutional revitalization with corporate farming models.
\end{abstract}

\section{KEY WORDS}

Revitalization, institutional farmers, rice farming, corporate farming.

In order to support South Sumatra attain self-sufficiency, in 2014, the central government through the Directorate General of Infrastructure, Ministry of Agriculture Republic of Indonesia provided assistance to open 2,250 hectares of new ricefields in five regencies of South Sumatra Province. The regencies that received the help are: Banyuasin (500 hectares), Musi Rawas (150 hectares), Ogan Komering llir (1100 hectares), South OKU (250 hectares), and East OKU (250 hectares) [Department of Agriculture South Sumatera, 2015].

Production and productivity of rice in South Sumatra still have great potential to be developed as a source of food, especially in tidal rice fields and swampy bog, with the growing expansion of IP-100 to IP-200, and the new paddy fields. Ogan Komering Ilir (OKI) is one of the three largest contributors of rice production in South Sumatra. In 2015 alone, OKI able to produce 542,291 tons of rice.

There are 157,846 hectares of extensive tidal wetland in South Sumatra, with 146,279 hectares of them already planted. Most of the land that has been planted are scattered in Ogan Komering Ilir area as much as 45,678 hectares (31.23 percent) [South Sumatra Provincial Agriculture Office, 2016].

This tidal area is sub-optimal (marginal) for agriculture. For that in the area, use reclaimed or improvements, an increase in the quality of land, partly tidal land in South Sumatra has been reclaimed. Change in acreage and productivity of paddy can be found in Table 1.

From the data it can be seen that the tidal area contribute approximately 1.10 million tonnes per year to rice production in South Sumatra. Research shows tidal wetlands have prospects to develop into agricultural land to support increase in agricultural production [Ismail et al. 1993]. But, although having good prospects, the use of tidal land for agriculture have obstacles, both biophysical and socio-economic and institutional. Institutional issues 
include weak institutional support for the provision of capital, means of production and marketing, as well as the accessibility of the area.

Table 1 - Harvested Area, Production and Average Production of Tidal Rice in South Sumatra, 2016

\begin{tabular}{cccc}
\hline Locations & Land Area (ha) & $\begin{array}{c}\text { Production (tons) } \\
\text { GKG }\end{array}$ & $\begin{array}{c}\text { The average production per hectare (t / ha) } \\
\text { GKG }\end{array}$ \\
\hline Ogan Komering llir & 26,434 & $127,940.561$ & 4.2 \\
Musi Banyuasin & 34,579 & $47,498.12$ & 4.28 \\
Banyuasin & 166,317 & $804,974.28$ & 4.84 \\
\hline Amount & 227,330 & $1,080,912.9$ & \\
\hline
\end{tabular}

Source: BPS South Sumatera Province (2016)

To implement a system of farming with corporate farming in rice farming in tidal ecosystem, the partnerships need confidence in the prospect of Industrial Forest Plantation (IFP) and sustainability to the farmers, given many limitations of farmers who could potentially be a constraint in the implementation of the institutional corporate farming system. The right partnerships, an institutional pattern that is consistent with the conditions of farmers and regional conditions of each region, as well as supporting factors following existing constraints are important factors to be studied previously in order to obtain the appropriate institutional model in its application.

Research issues. Based on the above, the problem of research formulated into a formulation of the problem as follows: "What is the state of potential revitalization of the institutional model of corporate farming in Ogan Komering Ilir».

Research purposes. Generally, this study aims to analyze the institutional system of corporate farming in Ogan Komering Ilir. Specifically, the purpose of this research is to analyze the factors that influence potential revitalization of the institutional system of corporate farming in Ogan Komering llir.

Hypothesis. The hypothesis of the study is aspects of human resources, management skills, coaching, social and cultural environment, farmers' knowledge of corporate farming, give positive effect to potential of corporate farming institution.

\section{METHODS OF RESEARCH}

Research Location and Period. The study was conduct in three sub districts in Ogan Komering Ilir Regency of South Sumatra Province, which are Tulung Selapan Sub district, Pangkalan Lampam Sub district, and Air Sugihan sub district. Those districts are select because those areas are peat area used for tidal rice farming and having partnership with Industrial Forest Plantation (IFP). This study was conducted in May 2015 until December 2015. The majority of data in this research are primary data, supported by secondary data. Location of the study is Simpang Heran Village, Bukit Batu Village, Rengas Merah Village, Srijaya Baru Village, and Simpang Tiga Sakti Village.

Research Population and Sample. The sampling method used is cluster sampling in peat swamp area because thuse area are area of peat that the designation have changed into Industrial Forest Plantation (IFP). Approach model in this research is region approach. To determine the size of the sample of the population, method by Neuman (2000) is used, i.e. for a population of approximately 1,000 (small) person the sample required are about 30 percent of the population, for a total population of about 10,000 the sample required are about 10 percent, while for a population of more than 150,000 (large,) 1 percent comparative sample is enough. In this study, the population has 1,804 members, so, the samples in this study is as many as 184 people (10 percent of population).

Analysis method. To determine the factors that influence the potential of farmer institution with corporate farming model, or to see the extent of free variables influencing variables bound as well to see how the research model designed (hypothetical) with a model of the real, inferential statistics models used are Structural Equation Modeling (SEM) analysis with PLS (Partial Leas Square) program. The variables measured in the study were: 
1) Human Resources (X1), 2) Management (X2), 3) Coaching (X3), 4) socio-cultural environment (X4), 5) characteristics of farmer organizations (X5), 6) Farmers' knowledge about corporate farming (X6), 7) Corporate farming potential (Y1).

\section{RESULTS AND DISCUSSION}

Characteristics of Respondents. The average age of respondents is 48 which is the productive age, according to Act No.13 of 2003 that state productive working age is from 15 to 64 years old. Then, more than 90 percent of respondents in this study are in the productive age.

Judging from the respondents' education, the average is still low. The low level of formal education the farmers in OKI had led to ability to manage farming becomes less than optimum. Levels of education will affect the mindset of farmers because the farmers of higher education will be familiar with the knowledge and make them easier to accept innovation.

Farming experience is adequately long, even reaching 40 years old. Rice farming experience will affect the level of farmers' skills in managing their farming. The longer farmers pursue farming the higher the skills, knowledge, and insights the farmers have, with respect to the farm managed. Farming experience is one of the factors that affect farmers in accepting an innovation. The low level of non-formal education of farmers related to the counseling or training which are not routinely held, and the tendency of farmers who attended training are only the group leader or their representation.

The majority of respondents have 3-4 person as household members, which are in moderate category, so the burden on these respondents are still moderate. So, the respondents have availability of workforce through labor by their family. A majority number of household members which is in moderate category can assist in the implementation of farmers institution revitalization with the corporate farming system.

Average production of paddy in Ogan Komering llir is 2.5 GKG per ha per one harvest season. One of the reasons of this low rice production number is sub-optimal performance of farmer institutions (groups, cooperatives). Therefore, institutional revitalization by corporate farming model is needed to increase production, income, and welfare of farmers.

Factors Affecting Potentials of Institutional Revitalization by Corporate Farming Systems In this study, the Component/variance Based Structural Equation Modeling is used to answer research issue that related the influence of human resources, management, development, socio-cultural environment, the characteristics of the institutional farmer and farmers' knowledge about corporate farming and its potential and its impact on readiness or expectation of farmers by institutional corporate farming.

From the structural model test results that have been obtained previously and factually, it can be said that the structural model fit to the data or models that may be applied to the stage of empirical generalization or hypothesis testing.

$$
Y 1=0.14 X 1+0.32 X 2+0.25 X 3+0.12 X 4+0.16 X 5+0.17 X 6, R^{2}=0.70
$$

Factors that affect the institutional potential corporate farming (Y1), respectively are:

1) Management Skills $(X 2)$ with a value $(\beta)=0.3$;

2) Coaching $(X 3)$ with a value $(\beta)=0.25$;

3 ) Knowledge of corporate farming farmers $(X 6)$ with the value $(\beta)=0.17$;

4) Characteristics of farmer organizations $(X 5)$, with a value $(\beta)=0.16$;

5) Human Resources (X1), with a value $(\beta)=0.14$;

6) Social and Cultural Environment $(X 4)$, with a value $(\beta)=0.12$.

The Effect of Management Skills to Institutional Revitalization by CorporateFarming Systems. Based on the partial test, the variables that greatly affect the potential revitalization of the institutional system of corporate farming is management skills. The facts above shows that the higher the skill of farmers, the higher the potential revitalization of the institutional system of corporate farming or the results showed that the variables management skills variable directly affect on farmers' potential institutional revitalization by corporate farming. 
The influence coefficient is 0.32 on real level $\alpha=0.05$ Influence of management skills on potential of institutional revitalization by corporate farming system reflected by 4 indicators that observed (manifest) consisting of Farming Planning (X2.1), the ability to carry out management functions (X2.2), experience of the organization (X2.3), and leadership (X2.4).

The experience of farmers' organizations is the most powerful indicator that reflects management skills in influencing potential institutional revitalization by the corporate farming system $(\lambda=0.90)$. $s$ that the better the experience of farmer organizations, the better the potential revitalization of farmer institutions by corporate farming system. Due to the experience of farmers' organizations the farmers are used to organize, the experience of these organizations greatly affect the potential to carry out an institutional system of the corporate farming.

Leadership is the second strongest influence after organizational experience variable to the potential of farmer institutional revitalization by corporate systems Faming $(\lambda=0.84)$. A positive value indicates that the influence coefficient is also positive indicators. This means that the better the leadership, the better the potential for institutional revitalization of farmers by the corporate farming system because they can mobilize the farming community around him. In the social interaction in the countryside in general, the presence of a highly respected leader is needed in the employment relationship or the situation involved another community relationships. Thus, in accepting something, new farmers will depend on the leaders included in the revitalization of farmer institutions by the corporate farming system. the better the leadership, the potential for institutional revitalization of farmers by corporate farming system will be more easily carried out by farmers.

Planning in farming is the third strongest influence after leadership variable in potential of institutional revitalization of farmers by corporate farming system $(\lambda=0.64)$. It means the better planning in farming, the better the potential revitalization of farmer institutions by corporate farming system.

Implementation of management functions in farming is the fourth strongest influence after leadership variable in institutional revitalization potential of farmers by the corporate farming systems $(\lambda=0.64)$. This means that the better performance of the functions of management in farming, the better the potential revitalization of farmer institutions by corporate farming system. The insufficient in number of farmers that carrying out the functions of management in farming means further implementation of management functions in the farming need to be optimized. Increasing in the performance of the functions of management in farming by farmers will increase potential of institutional revitalization of farmers by the corporate farming system.

Effect of Coaching on Potential of Institutional Revitalization by Corporate Farming Systems. Based on the partial test, one of the variables that greatly affect the potential revitalization of the institutional system of corporate farming is coaching. The facts above show that the higher guidance factor in farmers, the higher the potential revitalization of the institutional system of corporate farming or the results showed that coaching variables effect directly on farmers' potential institutional revitalization corporate farming, with influence coefficient of 0.31 on a real level á $=0.05$.

Coaching by private company to the farmers is the most powerful indicators that reflected guidance factor in influencing potential institutional revitalization by corporate farming system $(\lambda=0.81)$. This means that the better coaching by private company to the farmers, the better the potential for institutional revitalization of farmers by the corporate farming system. Coaching by the private company includes education, training conducted by the company to farmers as CSR program.

Government guidance is the second strongest influence variable, after coaching by private company, in potential of institutional revitalization of farmers by the corporate farming systems $(\lambda=0.64)$. This means that the better the guidance by government, the better the potential for institutional revitalization of farmers with corporate farming system. Guidance by the government through a group of farmers can help to explore the potential, troubleshoot farm farmer group members more effectively, and facilitate the access to information, 
markets, technology, capitalization, and the source [Medan City Agriculture Department, 2008].

Effect of Farmers Knowledge About Corporate Farming on Potential of Institutional Revitalization by Corporate Farming Systems. Their knowledge of institutional corporate farming is fifth strongest influence factor after farmer organizations characteristics to the potential characteristic of institutional corporate farming $(\beta=0.22)$.

From the analysis of the data shows that the farmers' knowledge about the understanding and implementation of corporate farming satisfies moderate criteria. This means that farmers' knowledge about the meaning and how the institutional implementation of the good corporate farming farmer is not fully known, but there are already some farmers who understand the implementation of the farm by way of pooling of land under one management. The reason is information and socialization they get about the institutional corporate farming is still very minimal.

The desire of farmers in the implementation of the institutional system of corporate farming is done by partnership. This desire is due to limited knowledge and the ability of farmers' capital. This means that the institutional implementation of farmers with the corporate farming system adapted to the wishes of farmers. The desire of farmers has become one of the variables found that affect the potential for institutional revitalization of farmers by corporate farming system. The harmony between the knowledge and the desire of farmers to institutional corporate farming will provide strong support to the institutional potential of corporate farming.

Effect of Potential Human Resources on Institutional Revitalization by Corporate Farming Systems. Based on the partial test, the second strongest variables that influence on potential institutional revitalization with corporate farming system are human resources. Based on the facts above shows, it can be shown that the higher the human resources variables, the higher the potential for institutional revitalization with corporate farming system, or the results showed that the variables of human resources directly effect on farmers' potential institutional revitalization corporate farming, with the influence coefficient of 0.28 on a real level $\alpha=0.05$. Corporate farming is not only institutional workforce but institutional business to empower human resources and to improve the ability of farmers' resources.

Age of farmers is the most powerful indicator that reflects the human resources factors in influencing potential institutional revitalization by the corporate farming system $(\lambda=0.89)$. This means that the higher the age of the farmer, the better the potential for institutional revitalization of farmers with the corporate farming system.

Non-formal education of farmers is the second most powerful indicator that reflects human resources factors in influencing potential institutional revitalization by the corporate farming system $(\lambda=0.88)$. This means that the higher the non-formal education of farmers, then the potential revitalization of farmer institutions with corporate farming system will be better.

Farmers experience is the third strongest indicator that reflecting human resources variables in influencing potential institutional revitalization bycorporate farming system $(\lambda=$ 0.85). This means that the longer the experience of farmers, the better the potential revitalization of farmer institutions by the corporate farming system. From the results of the research the average years of farming experience in the surveyed site is 21 years. This result suggests that the experience of farming is in old category. Farming experience affects the decisions regarding new technological innovations options.

Gender is the fourth strongest indicator that reflecting human resources variables in influencing potential institutional revitalization by corporate farming system $(\lambda=0.85)$. This means that more male farmers, the better the potential for institutional revitalization of farmers by corporate farming system.

Formal education of farmers is the sixth indicator that reflects the human resources in influencing potential institutional revitalization with the corporate farming system $(\lambda=0.63)$. This means that the higher the education of farmers, then the potential revitalization of farmer institutions by the corporate farming system will be better. Margono Slamet [1992] 
stated that the higher a person's education level, the higher the knowledge, attitudes and skills, working efficiency, know-how and techniques to work better and more profitable.

Effect of Characteristics of Farmers Organization on Institutional Revitalization by Corporate Farming Systems. The characteristics of farming institutions illustrate the inherent characteristics of the farming institutions that describe the condition of the institutions they have. The influence of farmer institutional characteristic on the potential of corporate farming institution is reflected by 4 manifest indicators, consisting of age of farmer institution (X51), number of member of farmer institution (X52), activity type (X53), and organizational structure (X55).

These results give meaning that the institutional characteristics of farmers will increase the institutional revitalization potential with the corporate farming system only if the four indicators are optimized. The higher quality of farmers' characteristics reflected by the age of the farmer institution, the number of members of the farming institution, the organizational structure, and the number of administrators will increase the institutional potential of corporate farming, both cultural and social potential, regional potential, structural potential and production potential. Organizational structure is an indicator of farmer institutional characteristics that have the greatest potential in reflecting the institutional characteristics of farmers in affecting the potential of corporate farming institutions $(\lambda=0.82)$. T his means that the better the institutional structure of farmers, the better the institutional potential by corporate farming system. The organizational structure itself describes the form of organizational management in terms of completeness of the organizational board components and tasks performed.

The performance of the board is the second ranking indicator that is able to reflect the influence of the variables of farmer institutional characteristics on the potential adoption of SISKA $(\lambda=0.57)$. This means that the performance of a good group management according to the perceptions of its members will also provide good potential to the revitalization of corporate farming institutional by group members. Conversely, if the employee performance is low (bad), then the revitalization potential of corporate farming by group members will also be low (bad). Good performance reflects good work contribution provided by the board for group activities including within the corporate farming organization.

The number of farmer group members is one of the indicators that proved able to reflect the variable of institutional characteristics of farmers in affecting the potential of corporate farming institutions $(\lambda=0.48)$. According to the Ministry of Agriculture [1998], the formation of an ideal farmer group consists of 20 to 30 people per group. This amount is considered the ideal number of candidates to be organized by one PPL in counseling and training. It is also possible to be managed and led by a group leader in carrying out group activities. Abdullah and Syamsu [2008] also stated that a farmer group formed on the basis of equal interests among farmers or farmers in the ideal amount of between 20-30 people will enable them to recognize each other's behavior, thus making the farmer group able to exist and have the ability to access all resources such as natural resources, human, capital, information, and facilities and infrastructure in developing the farms that they work. The age of the farming agency is an indicator that tends to reflect the length of experience of organization for its member farmers. This condition is very helpfull in implementation in the revitalization of corporate farming institutions. The newly formed institution when adopting an innovation requires a time of pre-adjustment between members and activities before adopting an innovation.

The Effect of Social, Economy, and Culture Environment on Institutional Revitalization Potential by Corporate Farming System. Based on the partial test, the sixth variables that affect the institutional revitalization potential by corporate farming system are the social, economic and cultural environment. From the above facts, there is indication that the higher the social, economic and cultural environment, the higher the potential for institutional revitalization Corporate farming system, with influence coefficient of 0.12 .

Socio-cultural value is indicator of social, economic and cultural values that have the greatest potential in reflecting the socio-cultural characteristics in influencing the potential of corporate farming institutions $(\lambda=0.83)$. It means that the better the socio-cultural value, the 
better the institutional potential with the corporate farming system. This research is also in line with the results of research Aminah et.al [2008] that concluded socio-cultural conditions will affect the behavior of farmers in managing land.

Farmers' access to counseling institutions, experts, and capital is an indicator of social, economic and cultural values that has the second greatest potential in reflecting sociocultural characteristics in influencing the potential of corporate farming institutions $(\lambda=0.81)$. This means that the better access to institutional counseling, research and capital, the better the institutional potential by corporate farming system. Farmers' access to counseling agencies and capital institutions is still low. Business capital is a major supporting factor in agricultural production activities. The intensity of workers counseling in the study area is still rare and not routinely done. Likewise, farmers' access to capital institutions such as financial institutions, both cooperatives and banks located at the village level and in the district, is low. In a farm without adequate capital, it is difficult for farmers to develop farming to achieve optimal production and maximum profit.

Access to transportation is the third indicator of social, economic and cultural values that reflecting socio-cultural characteristics in influencing the potential of corporate farming institutions $(\lambda=0.82)$. This means that the better the existing institutional system, the better the institutional potential with corporate farming system. Institutional system is viewed from the process. Farmers' access to transportation facilities is still low. It is necessary to increase transportation access to increase the potential of the corporate farming institutions. Access to the means of production is the fourth indicator of social, economic and cultural values that reflecting socio-cultural characteristics in influencing the potential of corporate farming institutions $(\lambda=0.75)$. Farmers' access to agricultural production facilities is still somewhat difficult. This difficulty level is caused by the availability, the high price, and the difficulties of obtaining agricultural production facilities in the research location. To optimize the institutional potential by the corporate farming system, it is necessary to increase the availability of production facilities such as seeds, fertilizer equipment, and others with the right price and time, as it will greatly support the success of farming. Given the means of agricultural production is one factor that is very important in supporting the potential of farmers institutions with thecorporate farming system then the farmers access to these production facilities need to be improved.

\section{CONCLUSION}

The result of SEM analysis is shows that factors influencing potential of institutional revitalization of tidal farming of tidal ecosystem with successive corporate farming model are: 1) Management Skills (X2), 2) Development (X3), Human Resources (X1), 3 ) Knowledge of farmers about corporate farming (X6), 4) Human Resources (X1), 5) characteristics of farming institutions (X5), 6) Socio-cultural environment (X4), these six variables significantly affect the revitalization potential of corporate farming institutions (Y1). Of the six variables: human resources (X1), characteristics of farming institutions (X5), and socio-cultural environment (X4) need to be optimized again to increase the revitalization potential of tidal rice farming ecosystem with corporate farming model.

\section{REFERENCES}

1. Afrizon, Isaac. A. 2011. Perception and Level of Farmer Adoption on System of Rice Intensification (SRI) Implementation in Bukit Peninjau I Village Sukaraja District Seluma District Bengkulu Province. Journal of Agriculture Informatics Vol.2 No.2 December 2011. 76-80.

2. Agriculture Department of South Sumatra. 2014. Annual Reports.

3. Agriculture Department of Ogan Komering Ilir Regency, 2014.

4. Anantanyu. 2009. Farmer Participation in Increasing Institutional Capacity of Farmer Groups. Dissertation of Graduate School IPB Bogor, (Not To Publish). 
5. Asmani. N. 2013. Sustainable Natural Resource Management Through Sustainable Food Farming Enterprises in the Framework of REDD. Proceeding National Seminar. PERHEPI.

6. 2013. Carbon Value Coverage Analysis and Benefits of Reforestation Ecosystem ForestBased Peat Swamp Forest Industry Patterns of Community Forestry Business Unit. PPS dissertation Sriwijaya University. Not published.

7. Central Bureau of Statistics. South Sumatera Province 2016. South Sumatera In Figures 2016. Central Bureau of Statistics. South Sumatra.

8. Central Bureau of Statistics. Ogan Komering Ilir District 2016. Ogan Komering Ilir In Figures 2016. Central statistics agency Ogan Komering Ilir.

9. Ismail.1993.Sewindu agricultural research on swamplands: Contribution and development prospects. Knowledge and education of farmers Research Project for Tidal and Swamp Land Farming- SWAMPS II. Agricultural Research Agency.

10. Ministry of Agriculture, 2007. Guidance on Growth, Development, and Combined Farmer Group, Permentan No.273 / Kpts.OT.160 / 4/2007 About Guidance of Farmers Institutional Development.

11. Mililer. Brent C. 1984. Family Research Methods. Sage Publication Baverly Hills London New Delhi.

12. Mosher, 1970. Getting Agricultural Moving How Moder Farming Can Provider A Better Life, Pyramid Book, New York.

13. Neuman, W. Lawrence. Social Research Methods. Qualitative and Quantitative Approaches Allyn and Bacon. Boston, 2000.

14. Pranadji, T, Sudaryanto, 1998. Study on Corporate Perceptions and Institutions for Rural Livestock Development (Case Study on Villages in Jambu Sub-district, Semarang District). Journal of Animal and Veterinary Science Vol. 4 No. 2 Th. 1998.

15. Reed, Edward, 1979. "Two Approachs to Cooperation in Rice Production South Korea" Dalam Group Farming in Asia. Editor John Wong. Singapura. Universitas Press.Kent Rigde. Singapura.

16. Riswani,2014, The Strategy of Institional Development and Plasma Implementation to Adopt Integration Syestem. of Cow and Palm Oil in South Sumatera.

17. Rogers,E.M., and F.F. Shoemaker. 1971. Communication of Innovations. A. Cross Cultural Approach. The Free Press. New York.

18. Slamet, 2003. Improving Public Participation in Rural Development in Establishing the Patterns of Human Behavior Development. Editor Ida Yustina and Ajad Sudradjat. IPB Press. Bogor.

19. Sjarkowi, F. 2010. Agribusiness Development Management. Baldad Grafiti Press, Issue I. Palembang.

20. Syahyuti, 2004. Institutional Model of Development Support in Lebak Area. Workshop Paper Lebak Field in South Kalimantan.

21. Uphoff, Norman Thomas. 1986. Local Institutional Development: An Analytical Sourcebook With Cases. Kumarian Press. 